IZA DP No. 4278

Paying More than Necessary?

The Wage Cushion in Germany

Sven Jung

Claus Schnabel

July 2009 


\title{
Paying More than Necessary? The Wage Cushion in Germany
}

\author{
Sven Jung \\ University of Erlangen-Nuremberg \\ Claus Schnabel \\ University of Erlangen-Nuremberg \\ and IZA
}

Discussion Paper No. 4278

July 2009

IZA

P.O. Box 7240

53072 Bonn

Germany

Phone: +49-228-3894-0

Fax: +49-228-3894-180

E-mail: iza@iza.org

Any opinions expressed here are those of the author(s) and not those of IZA. Research published in this series may include views on policy, but the institute itself takes no institutional policy positions.

The Institute for the Study of Labor (IZA) in Bonn is a local and virtual international research center and a place of communication between science, politics and business. IZA is an independent nonprofit organization supported by Deutsche Post Foundation. The center is associated with the University of Bonn and offers a stimulating research environment through its international network, workshops and conferences, data service, project support, research visits and doctoral program. IZA engages in (i) original and internationally competitive research in all fields of labor economics, (ii) development of policy concepts, and (iii) dissemination of research results and concepts to the interested public.

IZA Discussion Papers often represent preliminary work and are circulated to encourage discussion. Citation of such a paper should account for its provisional character. A revised version may be available directly from the author. 


\section{ABSTRACT \\ Paying More than Necessary? The Wage Cushion in Germany ${ }^{*}$}

Using a representative establishment data set for Germany, we show that more than 40 percent of plants covered by collective agreements pay wages above the level stipulated in the agreement, which gives rise to a wage cushion between the levels of actual and contractual wages. Cross-sectional and fixed-effects estimations for the period 2001-2006 indicate that the wage cushion mainly varies with the profit situation of the plant and with indicators of labour shortage and the business cycle. While plants bound by multi-employer sectoral agreements seem to pay wage premiums in order to overcome the restrictions imposed by the rather centralized system of collective bargaining in Germany, plants which make use of single-employer agreements are significantly less likely to have wage cushions.

JEL Classification: $\quad$ J30, J31

Keywords: $\quad$ wages, wage cushion, wage determination, bargaining, Germany

Corresponding author:

Claus Schnabel

Friedrich-Alexander-Universität Erlangen-Nürnberg

Lehrstuhl für Arbeitsmarkt- und Regionalpolitik

Lange Gasse 20

D-90403 Nürnberg

Germany

E-mail: claus.schnabel@wiso.uni-erlangen.de

\footnotetext{
* The authors would like to thank Boris Hirsch, Susanne Kohaut and Thorsten Schank for helpful comments and suggestions. The usual disclaimer applies.
} 


\section{INTRODUCTION}

In Germany, like in many other countries, employers usually complain that wages and labour costs are too high. At the same time, there is some evidence that quite a few employers in the private sector pay actual wages which are higher than the contractual wages negotiated in collective agreements. Unfortunately there are no official statistics on the existence and the size of this "wage cushion" (i.e. the difference between the levels of actual and contractual wages). ${ }^{1}$ The last official survey on the levels of actual and contractual wages was conducted in 1962 (see Decken 1964), and the German Federal Statistical Office nowadays only provides indices of the development of actual and contractual wages. ${ }^{2}$ In this paper, we use the IAB Establishment Panel, a representative annual survey of almost 16,000 establishments in Germany, to overcome this information deficit and analyze the presence, the size and the determinants of the wage cushion in Germany.

There are several reasons why such an analysis seems to be worthwhile. First, the presence of a wage cushion and the fraction of firms affected provide some information on the relative importance of (multi- or single-employer) collective wage bargaining by trade unions and employers associations on the one hand and of the determination of actual wages by individual firms on the other. Second, since a wage cushion reflects differences in actual wages between different firms, employees and regions (within the same bargaining unit), its size and development can also be interpreted as an indicator of wage differentiation and wage flexibility in the German system of wage determination, which is often regarded as rather rigid. Third, it will be interesting to see which factors influence the existence and the size of a wage cushion in individual establishments and whether these determinants are consistent with hypotheses derived from various theories of wage determination.

The paper proceeds as follows: Chapter 2 sketches the institutional background of wage determination in Germany and gives some descriptive information on the existence and the size of the wage cushion. Theoretical considerations on the determinants of the wage cushion are provided in Chapter 3 , while Chapter 4 presents the results of our econometric analysis. Chapter 5 concludes.

1 The expression "wage cushion", which seems to have been coined by Olivier Blanchard, has come into use recently in order to overcome certain ambiguities (see Cardoso and Portugal 2005, Bastos, Monteiro and Straume 2009). The older literature often uses the expressions "wage drift" (see, e.g., Gould 1967, Ordine 1996) or "wage gap" (see Gerfin 1969), both of which are somehow confusing. "Wage drift" is clearly a dynamic concept and should correctly refer only to the difference between the changes of actual and contractual wages, and "wage gap" has also been used to describe completely different concepts (such as gender wage gap or real wage gap). Other expressions used in the past are "wage glide", "wage slide" and "wage spread" (see Külp 1965: 201).

2 While in principle these indices can be used to calculate wage drift (i.e. the difference in the rates of change of actual and contractual wages), serious methodological problems suggest to be very cautious in interpreting such wage drift results (see Schnabel 1997: 134ff.). 


\section{INSTITUTIONAL BACKGROUND AND DESCRIPTIVE EVIDENCE}

In Germany, the constitutionally protected principle of bargaining autonomy gives organizations of employers and employees the right to regulate wages and working conditions without state interference. Collective agreements are legally binding and may be concluded either as multi-employer agreements at sectoral level or as single-employer agreements at firm level. In addition, firms have the right not to conclude collective agreements, in which case they make use of individual contracts with their employees. Collective bargaining is mainly conducted at the sectoral level in regional bargaining units, but in certain sectors it is quite frequent at national or firm level. The regional negotiations within one sector are closely coordinated by the officials of the appropriate sectoral trade union and employers association, so that variations between them are small (except for differences between western and eastern Germany which still exist in many sectors). Collective agreements determine blue and white collar pay (usually annually) as well as job classifications, working time and working conditions (over longer time periods). Collectively agreed norms are minimum standards, which means that firms bound by (sectoral- or firm-level) collective agreements cannot undercut, but only improve upon these terms and conditions. For instance, they may offer longer holidays or they pay higher wages than stipulated in the collective agreements, which leads to a wage cushion.

While the Federal Statistical Office does not provide statistics on bargaining coverage and the wage cushion, this information can be obtained from the representative IAB Establishment Panel (for a detailed description of this data set, see Fischer et al. 2009). The IAB Establishment Panel is drawn from a stratified sample of the plants included in the German employment statistics, where the strata are defined over industries and plant sizes (large plants are oversampled), but the sampling within each cell is random. The panel started in 1993 (1996) in western (eastern) Germany, and over time the number of establishments interviewed increased to almost 16,000, in order to allow regional analysis at the federal state level. Since the IAB Establishment Panel has been set up for the needs of the Federal Employment Agency, detailed information on the composition of the workforce and its development through time constitutes a major part of the questionnaire. Further questions include information on wages, profitability, establishment policies, and general information about the plant. Most important for our analysis, plants are also asked whether they are covered by collective agreements and whether they pay wages above the level stipulated in these agreements (if both is the case, they are asked to report the deviation in percent). 
Table 1: Bargaining coverage and presence of a wage cushion in the private sector, 2006

\begin{tabular}{|l|c|c|c|}
\hline & $\begin{array}{c}\text { western } \\
\text { Germany }\end{array}$ & $\begin{array}{c}\text { eastern } \\
\text { Germany }\end{array}$ & Germany \\
\hline number of plants surveyed & 8,002 & 4,618 & 12,620 \\
\hline $\begin{array}{l}\text { share of plants covered by a collective } \\
\text { agreement (in percent) }\end{array}$ & 36.2 & 20.6 & 33.2 \\
$\begin{array}{l}\text { - percentage of which pay wages as } \\
\text { stipulated in the collective agreement } \\
\text { - percentage of which pay wages above } \\
\text { the level stipulated in the collective }\end{array}$ & 53.6 & 80.3 & 56.7 \\
agreement & 46.4 & 19.7 & 43.3 \\
\hline $\begin{array}{l}\text { wage cushion } \\
\text { (amount by which actual wages lie } \\
\text { above contractual wages, in percent) } \\
\text { - in plants paying wages above the level } \\
\text { stipulated in the collective agreement } \\
\text { - in all plants covered by a collective } \\
\text { agreement }\end{array}$ & 10.4 & 10.7 & 10.4 \\
\hline
\end{tabular}

Notes: Weighted data, private sector only

Source: IAB Establishment Panel, wave 2006

Table 1 presents information on bargaining coverage and the presence of a wage cushion in the private sector (the public sector is excluded since public employers regard the contractual wages negotiated nationally as binding actual wages). It can be seen that in 2006 about one-third of plants (more precisely, 36 percent in western and 21 percent eastern Germany) were covered by a multi-employer or single-employer collective agreement. ${ }^{3}$ The majority of these plants did not deviate from the contractual wages stipulated in these agreements, which makes clear that collective bargaining between trade unions and employers associations is still very important in determining actual wages in Germany. That said, 46 percent of plants in western Germany and about 20 percent of plants in eastern Germany did pay wages above the level stipulated in the collective agreement. In these plants, the wage cushion (calculated as the amount by which actual wages exceeded contractual wages) was about 10 percent on average in western and eastern Germany. This implies that in the group of all plants covered by a collective agreement (including those not paying above the contractual wage) actual wages exceeded contractual wages by about 5 percent in western Germany and 2 percent in eastern Germany.

3 Since larger plants are more likely to be covered by collective agreements, bargaining coverage of employees is much higher. For the private plus public sector, Ellguth and Kohaut (2007) report that in 2006 about 65 (54) percent of employees in western (eastern) Germany were covered by collective agreements. Analyses of the determinants of collective bargaining structure are provided by Hübler and Jirjahn (2003) and by Schnabel, Zagelmeyer and Kohaut (2006). 
Table 2: Presence and size of the wage cushion according to plant size, 2006

\begin{tabular}{|l|c|c|c|c|}
\hline & \multicolumn{2}{|c|}{$\begin{array}{c}\text { share of plants covered by a } \\
\text { collective agreement that pay } \\
\text { wages above the level } \\
\text { stipulated in the collective } \\
\text { agreement (in percent) }\end{array}$} & \multicolumn{2}{|c|}{$\begin{array}{c}\text { wage cushion } \\
\text { (amount by which } \\
\text { actual wages lie above } \\
\text { contractual wages, in } \\
\text { percent) }\end{array}$} \\
\hline number of employees & $\begin{array}{c}\text { western } \\
\text { (on June 30, 2006) }\end{array}$ & $\begin{array}{c}\text { eastern } \\
\text { Germany }\end{array}$ & $\begin{array}{c}\text { Germany } \\
\text { Germany }\end{array}$ & $\begin{array}{c}\text { eastern } \\
\text { Germany }\end{array}$ \\
\hline 1 to 9 & 41.4 & 16.5 & 10.7 & 11.4 \\
10 to 49 & 54.3 & 21.0 & 10.1 & 10.7 \\
50 to199 & 59.0 & 38.8 & 9.6 & 8.4 \\
200 to 499 & 62.7 & 31.1 & 10.3 & 10.5 \\
500 and more & 65.7 & 19.5 & 11.4 & 9.9 \\
\hline total & 46.4 & 19.7 & 10.4 & 10.7 \\
\hline
\end{tabular}

Notes: Weighted data, private sector only

Source: IAB Establishment Panel, wave 2006

Table 2 indicates that in small plants with less than ten employees actual wages do not exceed contractual wages very often. In western Germany, the incidence of a wage cushion rises with plant size, whereas in eastern Germany this relationship looks hump-shaped. In both regions, the size of the wage cushion does not seem to vary systematically with plant size. ${ }^{4}$ Of course, it needs a multivariate analysis to clearly identify the relationship between plant size and the wage cushion.

\section{THEORETICAL EXPLANATIONS}

In the rather sparse literature on the wage cushion, basically four theoretical approaches can be distinguished. ${ }^{5}$ The institutional approach interprets the wage cushion as a mechanism to overcome the constraints imposed by multi-employer collective bargaining, allowing firms some room for manoeuvre in wage-setting (see Cardoso and Portugal 2005). Since in most cases bargaining in Germany is relatively centralized, collective agreements cannot take into account the specific situation of individual plants. They may also reflect egalitarian policies of trade unions. Furthermore, collective agreements contain a limited number of wage brackets for job classifications mainly based on formal qualification and tasks, which serve as a sort of minimum wages for employees who fall in the respective classifications. Firms which need to differentiate further or want to overcome the

4 The incidence and the size of the wage cushion also vary between sectors. They are relatively high in the investment goods producing sector (particularly in western Germany) and quite low in construction.

5 For more detailed discussions, see Külp (1965), Meyer (1994) and Schnabel (1997: ch. 6). Note that these explanations are not mutually exclusive. Muysken and van Veen (1996), for instance, present a model combining efficiency wage and bargaining explanations of the wage cushion. 
wage compression resulting from an egalitarian union wage policy can only do so by paying wages above the minimum stipulated in multi-employer agreements (or by switching to single-employer or no collective bargaining).

A traditional explanation of the wage cushion, which already can be found in Hansen and Rehn (1956), stresses the role of market forces and may thus be termed the market approach. Based on the neoclassical theory of labour supply and demand, the wage cushion (and wage drift) is simply interpreted as the result of excess demand for labour. If there is a shortage of labour in a certain segment of the labour market or in the aggregate labour market, actual wages go up (whereas contractual wages may not react so quickly). This will be particularly the case in times of full employment (see also Külp 1965: 238). In this approach, outside factors such as aggregate or regional unemployment should be the most important determinants of the wage cushion whereas factors inside the plant (for instance profitability) should not be relevant.

Market forces such as the labour market situation also play a role in bargaining theories of the wage cushion insofar as they affect the aims and opportunities of employees and employers at the plant level. In addition, all other factors that influence the bargaining position and the utility and profits of both sides are taken into account. Bargaining models usually take the contractual wage determined at the sectoral level as given and interpret wage setting at the firm level as a result of firm-specific bargaining between employers and trade unions (see, e.g., Holden 1990). Actual wages will be higher than stipulated in sectoral agreements if the economic situation and the ability to pay of the plant are better than assumed in sectoral bargaining and/or if the bargaining position of employees at plant level is better than at sectoral level. In Germany, the interests of employees at plant level are usually represented by works councils, which by law are excluded from reaching agreement with the employer on wages (unless sectoral agreements explicitly authorize such agreements). However, their extensive rights of information, consultation and co-determination on many other issues mean that works councils have considerable bargaining power which can be used for rentseeking and pushing through higher actual wages (see Addison, Schnabel and Wagner 2001, Hübler and Jirjahn 2003). ${ }^{6}$

While the previous two explanations assume that firms are forced to pay higher wages by the market or by the bargaining power of their employees, the efficiency wage approach (see, e.g., Weiss 1991) suggests that the wage cushion is an

6 Instead of resulting from explicit bargaining, the wage cushion could also be modeled as the result of anticipated or implied negotiations where the employer anticipates the results of an individual negotiation with her employee in order to save transaction costs (see Pull 1996). In this case, a wage cushion can even exist in the absence of trade unions or works councils at plant level. 
instrument of personnel policy voluntarily applied by firms in order to stimulate labour productivity. Assuming incomplete information about the motivation, effort and capability of their employees, firms may be willing to pay higher wages than stipulated in collective contracts in order to attract better qualified employees, avoid costly quits, reduce shirking and better motivate their workforce. The efficiency wage and thus the size of the wage cushion is the result of profit-maximizing behaviour of firms and reflects the determinants of employee effort such as the labour market situation, the level of alternative wages or the profitability of the firm (for instance via fairness considerations).

The fact that some potential determinants such as the labour market situation play a role in various explanations of the wage cushion discussed above and that these approaches are not mutually exclusive indicates that it will be very difficult to clearly distinguish empirically between alternative theoretical explanations. A significant influence of the labour market situation (measured by unemployment rates, vacancies or other indicators) was found in most previous analyses of the wage cushion in western Germany (see Meyer 1994, Bellmann and Kohaut 1995, Kohaut and Schnabel 2003). ${ }^{7}$ While Kohaut and Schnabel (2003) also obtained some evidence for the institutional approach, the finding by Meyer (1994) and Addison, Schnabel and Wagner (2001) that the wage cushion is significantly higher in plants where managers regard higher wages as an instrument for increasing employee motivation clearly points to the relevance of efficiency wage theory. Despite the problem of observational equivalence, theory may serve as a useful guide in selecting explanatory variables in the following empirical analysis of the wage cushion.

\section{EMPIRICAL ANALYSIS}

In contrast to Ordine (1996), Cardoso and Portugal (2005) and Bastos, Monteiro and Straume (2009), who analyze both the contractual wage and the wage cushion, lack of data on contractual wages in the plants that are our units of observation means that we are only able to investigate the presence and the size of a wage cushion in Germany. ${ }^{8}$ The IAB Establishment Panel data used include information

\footnotetext{
A number of studies have also analyzed wage drift in western Germany; see, e.g., Gerfin (1969), Gahlen and Ramser (1987) and Schnabel (1997). International analyses of wage drift can be found, inter alia, in Holden (1990), Lupi and Ordine (1993), Pehkonen and Viscari (1994) and Hibbs and Locking (1996).

8 The determinants of aggregate contractual wage changes are analyzed by Schnabel (1997) and Heilemann and Ulrich (2007). Due to lack of data on the contractual wages of individuals or plants, most studies for Germany analyze the level (or change) of actual wages. A typical finding is that actual wages are higher in plants covered by collective agreements, although this may partly reflect a non-random selection of firms and employees into collective bargaining regimes
} 
on a number of potential plant-level covariates and are supplemented by data on the regional unemployment rate at the level of districts. The explanatory variables employed are listed in Table 3 (summary statistics are reported in an appendix table). Their signs reflect their expected relationship with the wage cushion as stipulated in the various theoretical approaches sketched above (which of course can only be crudely represented in such a table). It can be seen that most variables are consistent with more than one theoretical approach, so that there will be few clear-cut hypotheses which can be used to empirically test the relevance of these theories.

Table 3: Expected relationship with the wage cushion of variables used in empirical estimations

\begin{tabular}{|c|c|c|c|c|}
\hline \multirow[b]{2}{*}{ explanatory variables } & \multicolumn{4}{|c|}{ theoretical approaches } \\
\hline & $\begin{array}{c}\text { institu- } \\
\text { tional }\end{array}$ & $\begin{array}{l}\text { market } \\
\text { forces }\end{array}$ & $\begin{array}{l}\text { bargaining } \\
\text { theories }\end{array}$ & $\begin{array}{l}\text { efficiency } \\
\text { wages }\end{array}$ \\
\hline $\begin{array}{l}\text { regional unemployment rate } \\
\text { (at district level, in percent) }\end{array}$ & & - & - & - \\
\hline $\begin{array}{l}\text { vacancy rate } \\
\text { (in percent of employment) }\end{array}$ & & + & + & + \\
\hline $\begin{array}{l}\text { vacancies for qualified jobs } \\
\text { (share of all vacancies, in percent) }\end{array}$ & & + & + & + \\
\hline $\begin{array}{l}\text { share of qualified employees } \\
\text { (in percent) }\end{array}$ & & & + & + \\
\hline $\begin{array}{l}\text { share of part-time employees } \\
\text { (in percent) }\end{array}$ & & & - & - \\
\hline $\begin{array}{l}\text { share of female employees } \\
\text { (in percent) }\end{array}$ & & & - & - \\
\hline $\begin{array}{l}\text { profit situation } \\
\text { (dummy: very good/good=1) }\end{array}$ & & & + & + \\
\hline $\begin{array}{l}\text { modern production technology } \\
\text { (dummy: } 1 \text { or } 2 \text { on } 5 \text {-point scale }=1 \text { ) }\end{array}$ & & & + & + \\
\hline $\begin{array}{l}\text { works council } \\
\text { (dummy: 1=yes) }\end{array}$ & & & + & \\
\hline $\begin{array}{l}\text { covered by firm-level agreement } \\
\text { (dummy: 1=yes) }\end{array}$ & - & & & \\
\hline $\begin{array}{l}\text { establishment size } \\
\text { (number of employees) }\end{array}$ & & & & + \\
\hline $\begin{array}{l}\text { difficulties in hiring skilled workers } \\
\text { expected (dummy: } 1=y e s)\end{array}$ & & + & + & + \\
\hline $\begin{array}{l}\text { insufficient employee motivation } \\
\text { expected (dummy: } 1=y e s \text { ) }\end{array}$ & & & & + \\
\hline
\end{tabular}

Note: The empirical estimations will also include two controls that cannot be related clearly to the theoretical approaches above, namely industry dummies and a dummy for branch plant status.

(see, e.g., Stephan and Gerlach 2005, Gürtzgen 2006). However, in these studies it cannot be distinguished whether higher actual wages are due to higher contractual wages or to a higher wage cushion at the plant level. 
A central determinant of the wage cushion in three of the four theoretical explanations discussed above is the labour market situation. We are able to include the regional unemployment rate (at the district level) as well as the plant's vacancy rate and its share of vacancies for qualified jobs as explanatory variables. The higher the unemployment rate and the lower the two vacancy rates, the lower should be the wage cushion. In order to reduce problems of reverse causality, these three explanatory variables will be lagged by one year.

We also take account of the structure of the workforce by including the employment shares of qualified (i.e. medium-skilled and skilled) workers, part-time workers and women as explanatory variables. Previous analyses with disaggregated data (cf. Schnabel 1997: $159 \mathrm{ff}$.) suggest that qualified employees are more often and to a larger extent paid above the contractual wage, since quits of this group would be relatively costly. In contrast, the lower labour force attachment and tenure of women and part-time workers (resulting in lower firm-specific human capital) suggest that these groups will rarely be paid wages above the contractual level. This reasoning is consistent both with efficiency wage and bargaining explanations of the wage cushion, but these variables should not play a role according to the market approach.

In contrast to the institutional and the market approach, both bargaining theory and the fair-wage variant of efficiency wage theory suggest that the existence and size of the wage cushion depend positively on the plant's profitability. We therefore include a dummy variable indicating whether managers regarded the profit situation in the previous year as very good or good. A similar dummy variable reflects a modern production technology in the plant, which is expected to correlate positively with the wage cushion. State-of-the-art technology may indicate the presence of quasi-rents and favour rent-sharing, but it could also mean that plants have to attract and motivate high-skilled employees by paying wage premiums.

While the previous explanatory variables are each consistent with more than one theoretical explanation, there are some covariates that only play a role in a single approach and thus can be used to crudely discriminate between theories. For instance, we are able to include a dummy variable reflecting the existence or not of a works council in the plant (lagged by one year to avoid endogeneity problems that could result if employees chose to erect a works council in order to obtain a higher wage cushion). According to bargaining theory, the existence of a works council with substantial bargaining power in many areas should result in a higher wage cushion.

The institutional approach sketched above relates the presence of a wage cushion to the fact that collective agreements at sectoral level cannot take into account the 
specific situation of individual plants. This hypothesis can be tested by including a dummy variable for the existence of a firm-level (rather than a sectoral-level) collective agreement. Since such an agreement actually can take into account the firm-specific situation, the wage cushion should be considerably lower or even nonexistent in plants with such firm-level agreements. The regression coefficient of this dummy variable is therefore expected to be negative.

According to efficiency wage theory, the size of a plant should be positively correlated with the wage cushion. The larger plants are, the more complex are organizational structures and the more difficult is it for management to supervise and monitor employees, so that it may make sense to pay wage premiums as incentives. In order to allow for a non-linear relationship, plant size is included in linear and quadratic form in the estimations.

In the 2006 wave of the IAB Establishment Panel, managers were also asked which problems of personnel policy they expected in the next two years. We may thus include a dummy variable reflecting difficulties in hiring skilled employees, which should play a role for the wage cushion according to the market approach, the bargaining approach and the adverse selection variant of efficiency wage theory. Another dummy variable takes on the value of one if managers expected an insufficient motivation of their employees, which according to efficiency wage theory could be overcome by a wage premium and thus should result in a (higher) wage cushion. However, since these two dummy variables refer to expected future problems and could be endogenous, they should be interpreted cautiously. ${ }^{9}$ In our estimations we will therefore present two models, one excluding these variables (model 1) and one including them (model 2).

Finally, we add two control variables that cannot be related clearly to the theoretical explanations in Chapter 3. A branch plant/subsidiary dummy variable catches the possibility that due to spill-over effects from their (large) mother company establishments in multi-plant organizations might be more likely to have wage cushions than independent plants. We also control for sector affiliation by including eleven industry dummies.

9 Note that while the wage cushion would be higher if managers expect and try to avoid difficulties in hiring skilled workers and insufficient employee motivation, a reverse causality (i.e. that an insufficient wage cushion creates hiring and motivation problems) would result in a negative relationship between these two dummy variables and the wage cushion. 
Table 4: Determinants of the wage cushion, 2006

(only private sector plants covered by a collective agreement; tobit estimations; dependent variable is size of the wage cushion in percent)

\begin{tabular}{|c|c|c|c|c|}
\hline \multirow[b]{2}{*}{ explanatory variables } & \multicolumn{2}{|c|}{ model 1} & \multicolumn{2}{|c|}{ model 2} \\
\hline & $\begin{array}{l}\text { western } \\
\text { Germany }\end{array}$ & $\begin{array}{l}\text { eastern } \\
\text { Germany }\end{array}$ & $\begin{array}{l}\text { western } \\
\text { Germany }\end{array}$ & $\begin{array}{l}\text { eastern } \\
\text { Germany }\end{array}$ \\
\hline $\begin{array}{l}\text { regional unemployment rate } \ddagger \\
\text { (at district level, in percent) }\end{array}$ & $\begin{array}{l}-0.1969 \\
(-1.53)\end{array}$ & $\begin{array}{l}-0.5789^{* \star \star} \\
(-2.68)\end{array}$ & $\begin{array}{l}-0.1863 \\
(-1.46)\end{array}$ & $\begin{array}{l}-0.5795^{\star * *} \\
(-2.76)\end{array}$ \\
\hline $\begin{array}{l}\text { vacancy rate } \ddagger \\
\text { (in percent of employment) }\end{array}$ & $\begin{array}{l}0.0015 \\
(1.49)\end{array}$ & $\begin{array}{c}-0.0415 \\
(-0.41)\end{array}$ & $\begin{array}{l}0.0011 \\
(1.05)\end{array}$ & $\begin{array}{l}-0.0724 \\
(-0.68)\end{array}$ \\
\hline $\begin{array}{l}\text { vacancies for qualified jobs } \ddagger \\
\text { (share of all vacancies, in percent) }\end{array}$ & $\begin{array}{l}0.0260^{* * *} \\
(3.93)\end{array}$ & $\begin{array}{c}0.0468 * \\
(1.95)\end{array}$ & $\begin{array}{l}0.0206^{* * *} \\
(2.96)\end{array}$ & $\begin{array}{l}0.0387 \\
(1.63)\end{array}$ \\
\hline $\begin{array}{l}\text { share of qualified employees } \\
\text { (in percent) }\end{array}$ & $\begin{array}{l}0.0022 \\
(0.19)\end{array}$ & $\begin{array}{l}-0.0320 \\
(-1.02)\end{array}$ & $\begin{array}{l}0.0105 \\
(0.96)\end{array}$ & $\begin{array}{c}-0.0302 \\
(-0.93)\end{array}$ \\
\hline $\begin{array}{l}\text { share of part-time employees } \\
\text { (in percent) }\end{array}$ & $\begin{array}{c}-0.0638^{\star \star \star} \\
(-4.10)\end{array}$ & $\begin{array}{l}-0.0110 \\
(-0.28)\end{array}$ & $\begin{array}{c}-0.0577^{\star \star *} \\
(-3.84)\end{array}$ & $\begin{array}{c}-0.0055 \\
(-0.14)\end{array}$ \\
\hline $\begin{array}{l}\text { share of female employees } \\
\text { (in percent) }\end{array}$ & $\begin{array}{c}-0.0244 \\
(-1.61)\end{array}$ & $\begin{array}{l}-0.0653 \\
(-1.55)\end{array}$ & $\begin{array}{c}-0.0247 \\
(-1.61)\end{array}$ & $\begin{array}{c}-0.0630 \\
(-1.61)\end{array}$ \\
\hline $\begin{array}{l}\text { profit situation } \ddagger \\
\text { (dummy: very good/good=1) }\end{array}$ & $\begin{array}{l}1.5273^{\star \star *} \\
(3.13)\end{array}$ & $\begin{array}{l}3.3957^{\star \star *} \\
(2.58)\end{array}$ & $\begin{array}{l}1.4536^{\star \star \star} \\
(3.02)\end{array}$ & $\begin{array}{l}3.7067^{\star \star \star} \\
(2.82)\end{array}$ \\
\hline $\begin{array}{l}\text { modern production technology } \\
\text { (dummy: } 1 \text { or } 2 \text { on } 5 \text {-point scale=1) }\end{array}$ & $\begin{array}{l}1.1922^{* *} \\
(2.27)\end{array}$ & $\begin{array}{c}2.4274^{*} \\
(1.79)\end{array}$ & $\begin{array}{l}1.1494^{* *} \\
(2.17)\end{array}$ & $\begin{array}{l}2.1896 \\
(1.61)\end{array}$ \\
\hline $\begin{array}{l}\text { works council } \ddagger \\
\text { (dummy: } 1=y e s \text { ) }\end{array}$ & $\begin{array}{c}-0.4069 \\
(-0.59)\end{array}$ & $\begin{array}{l}1.7269 \\
(1.08)\end{array}$ & $\begin{array}{c}-0.2390 \\
(-0.37)\end{array}$ & $\begin{array}{c}2.3094 \\
(1.41)\end{array}$ \\
\hline $\begin{array}{l}\text { covered by firm-level agreement } \\
\text { (dummy: 1=yes) }\end{array}$ & $\begin{array}{c}-4.2948^{* * *} \\
(-4.47)\end{array}$ & $\begin{array}{c}-5.6758^{* * *} \\
(-3.20)\end{array}$ & $\begin{array}{c}-4.3056^{\star * *} \\
(-4.47)\end{array}$ & $\begin{array}{c}-5.9370^{* * *} \\
(-3.27)\end{array}$ \\
\hline $\begin{array}{l}\text { establishment size } \\
\text { (number of employees) }\end{array}$ & $\begin{array}{c}0.0005^{\star} \\
(1.64)\end{array}$ & $\begin{array}{c}0.0011 \\
(0.25)\end{array}$ & $\begin{array}{c}0.0006^{*} \\
(1.72)\end{array}$ & $\begin{array}{l}-0.0035 \\
(-0.73)\end{array}$ \\
\hline establishment size squared & $\begin{array}{l}-1.87 e-8^{*} \\
(-1.88)\end{array}$ & $\begin{array}{l}-2.56 \text { e-6 } \\
(-1.22)\end{array}$ & $\begin{array}{l}-1.84 \text { e-8* } \\
(-1.90)\end{array}$ & $\begin{array}{l}-9.70 \text { e-7 } \\
(-0.46)\end{array}$ \\
\hline $\begin{array}{l}\text { branch plant/subsidiary } \\
\text { (dummy: 1=yes) }\end{array}$ & $\begin{array}{l}1.0136 \\
(1.52)\end{array}$ & $\begin{array}{c}2.4608 \\
(1.44)\end{array}$ & $\begin{array}{l}0.8380 \\
(1.29)\end{array}$ & $\begin{array}{l}1.9731 \\
(1.12)\end{array}$ \\
\hline $\begin{array}{l}\text { difficulties in hiring skilled workers } \\
\text { expected (dummy: } 1=y e s)\end{array}$ & & & $\begin{array}{l}1.8229^{* * *} \\
(2.84)\end{array}$ & $\begin{array}{l}4.2591^{* *} \\
(2.22)\end{array}$ \\
\hline $\begin{array}{l}\text { insufficient employee motivation } \\
\text { expected (dummy: } 1=y e s \text { ) }\end{array}$ & & & $\begin{array}{c}1.7312^{* *} \\
(2.06)\end{array}$ & $\begin{array}{l}5.2515 \\
(1.45)\end{array}$ \\
\hline industry dummies & yes $^{* * *}$ & yes $^{* * *}$ & yes $^{* * *}$ & yes $^{\star \star *}$ \\
\hline number of plants $n$ & $\begin{array}{l}2,990 \\
7.88^{\star * \star}\end{array}$ & $\begin{array}{c}1,175 \\
4.52^{\star \star *}\end{array}$ & $\begin{array}{l}2,975 \\
8.24^{\star * *} \\
0.0159\end{array}$ & $\begin{array}{c}1,171 \\
4.28^{* \star *} \\
0.0267\end{array}$ \\
\hline
\end{tabular}

Notes: Robust t-values (based on standard errors adjusted for clustering at the district level) in brackets. ${ }^{* / * * / * * *}$ denote statistical significance at the $10 / 5 / 1$ percent level. $\ddagger$ indicates that the information refers to the previous year.

Source: IAB Establishment Panel, wave 2006; own estimations. 
The results of our empirical investigations using data from the IAB Establishment Panel for the year 2006 are reported in Tables 4 and 5. Due to the different labour market situation and the vast differences in bargaining coverage and the presence of a wage cushion visible in Table 1, we present separate estimations for western and eastern Germany. In Table 4, the dependent variable is the size of the wage cushion in percent. Since this cannot become negative and since a large share of plants covered by collective agreements does not pay higher actual than contractual wages (see Table 1), so that the wage cushion is often zero, we use the tobit estimation procedure (for details on this method, see Greene 2000: ch. 20).

The results for models 1 and 2 presented in Table 4 show that not all covariates play a significant role in explaining the wage cushion. It can be seen that in both parts of Germany the wage cushion is positively related to the profitability and the state of production technology of the plant. It is lower in plants covered by firm-level agreements and higher if managers expect difficulties in hiring skilled workers. The share of vacancies for qualified jobs (but not the overall vacancy rate) also plays a role, whereas the external labour market situation is significantly related to the wage cushion in eastern Germany but does not reach conventional levels of significance in western Germany. In contrast, the employment share of part-timers, plant size and managers' expectations concerning insufficient employee motivation are only significant in western Germany.

While the tobit estimation procedure used in Table 4 combines information on the presence and the size of the wage cushion, Table 5 presents separate estimations (of model 1 only) for the presence of the wage cushion (using the probit method) and of the size of the wage cushion in those plants paying wages above the contractual level (using a truncated regression model). It can be seen that our model is mainly able to explain the presence of a wage cushion whereas the truncated regression model on the size of this cushion proves to be insignificant. Interestingly, however, even at the 10 percent level of significance a likelihood ratio test (as suggested by Greene 2000: 915) does not reject the more restrictive tobit model applied in Table 4 in favour of the separate estimations in Table 5. 
Table 5: Determinants of the presence and size of a wage cushion, 2006 (only private sector plants covered by a collective agreement; dependent variables are a dummy for the presence and the size of the wage cushion in percent, respectively)

\begin{tabular}{|c|c|c|c|c|}
\hline \multirow[b]{2}{*}{ explanatory variables } & \multicolumn{2}{|c|}{ probit estimation } & \multicolumn{2}{|c|}{ truncated regression } \\
\hline & $\begin{array}{l}\text { western } \\
\text { Germany }\end{array}$ & $\begin{array}{l}\text { eastern } \\
\text { Germany }\end{array}$ & $\begin{array}{l}\text { western } \\
\text { Germany }\end{array}$ & $\begin{array}{l}\text { eastern } \\
\text { Germany }\end{array}$ \\
\hline $\begin{array}{l}\text { regional unemployment rate } \ddagger \\
\text { (at district level, in percent) }\end{array}$ & $\begin{array}{c}-0.0230^{* *} \\
(-2.05)\end{array}$ & $\begin{array}{l}-0.0286^{* *} \\
(-2.32)\end{array}$ & $\begin{array}{l}0.1473 \\
(0.83)\end{array}$ & $\begin{array}{l}0.4217 \\
(0.80)\end{array}$ \\
\hline $\begin{array}{l}\text { vacancy rate } \ddagger \\
\text { (in percent of employment) }\end{array}$ & $\begin{array}{c}0.0008^{\star \star} \\
(2.25)\end{array}$ & $\begin{array}{l}-0.0027 \\
(-0.52)\end{array}$ & $\begin{array}{c}-0.0139^{*} \\
(-1.67)\end{array}$ & $\begin{array}{l}0.1256 \\
(0.30)\end{array}$ \\
\hline $\begin{array}{l}\text { vacancies for qualified jobs } \ddagger \\
\text { (share of all vacancies, in percent) }\end{array}$ & $\begin{array}{l}0.0026^{\star \star \star} \\
(3.93)\end{array}$ & $\begin{array}{c}0.0029^{*} \\
(1.88)\end{array}$ & $\begin{array}{l}0.0218 \\
(1.26)\end{array}$ & $\begin{array}{l}0.0164 \\
(0.30)\end{array}$ \\
\hline $\begin{array}{l}\text { share of qualified employees } \\
\text { (in percent) }\end{array}$ & $\begin{array}{c}-0.0005 \\
(-0.51)\end{array}$ & $\begin{array}{c}-0.0035^{*} \\
(-1.74)\end{array}$ & $\begin{array}{l}0.0425 \\
(0.98)\end{array}$ & $\begin{array}{l}0.1046 \\
(1.06)\end{array}$ \\
\hline $\begin{array}{l}\text { share of part-time employees } \\
\text { (in percent) }\end{array}$ & $\begin{array}{c}-0.0051^{* * *} \\
(-3.90)\end{array}$ & $\begin{array}{c}-0.0008 \\
(-0.41)\end{array}$ & $\begin{array}{l}-0.0981 \\
(-1.32)\end{array}$ & $\begin{array}{l}-0.0290 \\
(-0.26)\end{array}$ \\
\hline $\begin{array}{l}\text { share of female employees } \\
\text { (in percent) }\end{array}$ & $\begin{array}{c}-0.0027^{* *} \\
(-2.10)\end{array}$ & $\begin{array}{c}-0.0045^{\star} \\
(-1.86)\end{array}$ & $\begin{array}{l}0.0170 \\
(0.43)\end{array}$ & $\begin{array}{l}-0.0037 \\
(-0.06)\end{array}$ \\
\hline $\begin{array}{l}\text { profit situation } \ddagger \\
\text { (dummy: very good/good=1) }\end{array}$ & $\begin{array}{l}0.1854^{\star * *} \\
\quad(3.83)\end{array}$ & $\begin{array}{l}0.1898^{* *} \\
(2.27)\end{array}$ & $\begin{array}{l}-0.0938 \\
(-0.08)\end{array}$ & $\begin{array}{l}3.2526 \\
(0.77)\end{array}$ \\
\hline $\begin{array}{l}\text { modern production technology } \\
\text { (dummy: } 1 \text { or } 2 \text { on } 5 \text {-point scale }=1 \text { ) }\end{array}$ & $\begin{array}{l}0.1515^{\star * *} \\
\quad(3.03)\end{array}$ & $\begin{array}{c}0.1591^{*} \\
(1.88)\end{array}$ & $\begin{array}{c}-1.2758 \\
(-0.59)\end{array}$ & $\begin{array}{l}-0.2407 \\
(-0.05)\end{array}$ \\
\hline $\begin{array}{l}\text { works council } \ddagger \\
\text { (dummy: } 1=y e s \text { ) }\end{array}$ & $\begin{array}{l}0.0521 \\
(0.90)\end{array}$ & $\begin{array}{l}0.1288 \\
(1.30)\end{array}$ & $\begin{array}{l}-3.5028 \\
(-1.40)\end{array}$ & $\begin{array}{l}-2.0336 \\
(-0.48)\end{array}$ \\
\hline $\begin{array}{l}\text { covered by firm-level agreement } \\
\text { (dummy: 1=yes) }\end{array}$ & $\begin{array}{c}-0.4054^{* * *} \\
(-5.32)\end{array}$ & $\begin{array}{c}-0.3646^{\star \star *} \\
(-3.59)\end{array}$ & $\begin{array}{c}-3.2404 \\
(-0.95)\end{array}$ & $\begin{array}{c}2.2171 \\
(0.41)\end{array}$ \\
\hline $\begin{array}{l}\text { establishment size } \\
\text { (number of employees) }\end{array}$ & $\begin{array}{c}0.0001^{*} \\
(1.65)\end{array}$ & $\begin{array}{l}0.0001 \\
(0.60)\end{array}$ & $\begin{array}{l}0.0008 \\
(0.77)\end{array}$ & $\begin{array}{l}-0.0124 \\
(-0.86)\end{array}$ \\
\hline establishment size squared & $\begin{array}{l}-1.88 e-9^{* *} \\
(-2.02)\end{array}$ & $\begin{array}{l}-1.64 \mathrm{e}-7 \\
(-1.26)\end{array}$ & $\begin{array}{c}-3.17 \text { e-8 } \\
(-0.76)\end{array}$ & $\begin{array}{l}-2.11 e-6 \\
(-0.28)\end{array}$ \\
\hline $\begin{array}{l}\text { branch plant/subsidiary } \\
\text { (dummy: } 1=y e s)\end{array}$ & $\begin{array}{c}0.1122^{*} \\
(1.79)\end{array}$ & $\begin{array}{l}0.0688 \\
(0.64)\end{array}$ & $\begin{array}{l}0.3760 \\
(0.23)\end{array}$ & $\begin{array}{c}9.4394^{*} \\
(1.95)\end{array}$ \\
\hline industry dummies & yes $^{* * *}$ & yes $^{* *}$ & yes & yes \\
\hline $\begin{array}{l}\text { number of plants } n \\
X^{2}(23) \\
\text { pseudo } R^{2}\end{array}$ & $\begin{array}{c}3,082 \\
238.21^{\star \star *} \\
0.0576\end{array}$ & $\begin{array}{c}1,192 \\
113.55^{\star \star *} \\
0.0548 \\
\end{array}$ & $\begin{array}{l}1,599 \\
10.01\end{array}$ & $\begin{array}{c}292 \\
30.77\end{array}$ \\
\hline
\end{tabular}

Notes: Robust z-values (based on standard errors adjusted for clustering at the district level) in brackets. ${ }^{* * * / * * *}$ denote statistical significance at the $10 / 5 / 1$ percent level. $\ddagger$ indicates that the information refers to the previous year.

Source: IAB Establishment Panel, wave 2006; own estimations. 
Interpreting the results in Tables 4 and 5 in terms of the four theoretical approaches sketched in chapter 3, there is at least partial support for each of these explanations. The institutional hypothesis is confirmed since plants which make use of firm-level collective agreements that enable them to take firm-specific conditions explicitly into consideration are significantly less likely to have wage cushions. The statistical significance of various indicators of labour shortage and of the regional unemployment rate is in accordance with the market forces approach, but of course it is also consistent with other theories. However, the fact that the profit situation of the plant also plays a significant role is inconsistent with a pure institutional or market explanation of the wage cushion. While most of the covariates suggested by bargaining theories (such as profitability and labour shortages) are found to be significant, the statistical insignificance of the crucial works council variable casts some doubt on the bargaining explanation. Finally, most of the explanatory variables derived from efficiency wage theory prove to be significant, but only in western Germany there is weak statistical evidence for the relevance of plant size the only variable that solely plays a role in this approach. Taken together, these results suggest that the wage cushion cannot be explained by one theoretical approach only.

In order to exploit the panel character of our data and to provide a sort of robustness check of our results from the cross-sectional analyses in Tables 4 and 5, we also perform fixed effects estimation for the period 2001-2006 (although this reduces the sample size by about 80 percent). Since fixed effects tobit estimation is not feasible, since information on the size of the wage cushion is not available in every year and since Table 5 has shown that the explanatory power of our model is largely restricted to presence of a wage cushion, we make use of fixed effect logit analyses of the presence or not of a wage cushion. The results of these panel estimations for western and eastern Germany are presented in Table 6 for two alternative specifications with and without year dummies. ${ }^{10}$

10 The observation period 2000-2006 results from the fact that from the wave 2000 on the number of plants surveyed by the IAB Establishment Panel has increased substantially, and we need to take lagged variables from this wave. We first obtained pooled logit estimates for 2001-2006, which were largely consistent with the cross-sectional estimates of wage cushion presence for 2006 shown in Table 5 (except that the works council variable now had a significant coefficient in western Germany). We then performed a Hausman test (see Greene 2000: 841) which preferred the fixed effects logit model presented in Table 6 rather than the pooled logit model (the results of which are available on request). 
Table 6: Determinants of the presence of a wage cushion, 2001-2006 (only private sector plants covered by a collective agreement; fixed effects logit estimates; dependent variable is a dummy for the presence of a wage cushion)

\begin{tabular}{|c|c|c|c|c|}
\hline explanatory variables & \multicolumn{2}{|c|}{ western Germany } & \multicolumn{2}{|c|}{ eastern Germany } \\
\hline $\begin{array}{l}\text { regional unemployment rate } \ddagger \\
\text { (at district level, in percent) }\end{array}$ & $\begin{array}{c}-0.2498^{\star \star \star} \\
(-4.29)\end{array}$ & $\begin{array}{c}0.0083 \\
(0.06)\end{array}$ & $\begin{array}{l}-0.1285 \\
(-0.91)\end{array}$ & $\begin{array}{c}-0.1183 \\
(-0.53)\end{array}$ \\
\hline $\begin{array}{l}\text { vacancy rate } \ddagger \\
\text { (in percent of employment) }\end{array}$ & $\begin{array}{c}0.0017 \\
(0.32)\end{array}$ & $\begin{array}{l}0.0004 \\
(0.07)\end{array}$ & $\begin{array}{c}-0.0059 \\
(-1.04)\end{array}$ & $\begin{array}{l}-0.0063 \\
(-1.08)\end{array}$ \\
\hline $\begin{array}{l}\text { vacancies for qualified jobs } \ddagger \\
\text { (share of all vacancies, in percent) }\end{array}$ & $\begin{array}{c}-0.0004 \\
(-0.34)\end{array}$ & $\begin{array}{l}-0.0013 \\
(-1.22)\end{array}$ & $\begin{array}{c}-0.0002 \\
(-0.11)\end{array}$ & $\begin{array}{l}-0.0003 \\
(-0.14)\end{array}$ \\
\hline $\begin{array}{l}\text { share of qualified employees } \\
\text { (in percent) }\end{array}$ & $\begin{array}{l}0.0023 \\
(0.79)\end{array}$ & $\begin{array}{l}0.0038 \\
(1.28)\end{array}$ & $\begin{array}{l}0.0018 \\
(0.29)\end{array}$ & $\begin{array}{l}0.0016 \\
(0.26)\end{array}$ \\
\hline $\begin{array}{l}\text { share of part-time employees } \\
\text { (in percent) }\end{array}$ & $\begin{array}{c}-0.0037 \\
(-1.27)\end{array}$ & $\begin{array}{c}-0.0034 \\
(-1.17)\end{array}$ & $\begin{array}{c}0.0071 \\
(1.09)\end{array}$ & $\begin{array}{c}0.0084 \\
(1.28)\end{array}$ \\
\hline $\begin{array}{l}\text { share of female employees } \\
\text { (in percent) }\end{array}$ & $\begin{array}{l}0.0023 \\
(0.46)\end{array}$ & $\begin{array}{l}0.0018 \\
(0.38)\end{array}$ & $\begin{array}{c}0.0150^{*} \\
(1.76)\end{array}$ & $\begin{array}{c}0.0136 \\
(1.61)\end{array}$ \\
\hline $\begin{array}{l}\text { profit situation } \ddagger \\
\text { (Dummy: very good/good=1) }\end{array}$ & $\begin{array}{l}0.3007^{\star * *} \\
(3.33)\end{array}$ & $\begin{array}{l}0.2611^{* \star *} \\
\quad(2.82)\end{array}$ & $\begin{array}{c}0.2295^{*} \\
(1.92)\end{array}$ & $\begin{array}{l}0.1970 \\
(1.63)\end{array}$ \\
\hline $\begin{array}{l}\text { modern production technology } \\
(\text { dummy: } 1 \text { or } 2 \text { on } 5 \text {-scale index }=1)\end{array}$ & $\begin{array}{l}-0.1519 \\
(-1.54)\end{array}$ & $\begin{array}{l}-0.1858^{*} \\
(-1.93)\end{array}$ & $\begin{array}{l}0.2016 \\
(1.14)\end{array}$ & $\begin{array}{l}0.1847 \\
(1.06)\end{array}$ \\
\hline $\begin{array}{l}\text { works council } \ddagger \\
\text { (Dummy: } 1=\text { yes) }\end{array}$ & $\begin{array}{l}0.1373 \\
(0.59)\end{array}$ & $\begin{array}{c}0.0917 \\
(0.42)\end{array}$ & $\begin{array}{c}0.0553 \\
(0.16)\end{array}$ & $\begin{array}{l}0.1186 \\
(0.33)\end{array}$ \\
\hline $\begin{array}{l}\text { covered by firm-level agreement } \\
\text { (Dummy: } 1=y e s)\end{array}$ & $\begin{array}{c}-0.5496^{\star \star *} \\
(-3.09)\end{array}$ & $\begin{array}{l}-0.5247^{* * *} \\
(-2.91)\end{array}$ & $\begin{array}{l}-0.1965 \\
(-0.83)\end{array}$ & $\begin{array}{l}-0.2174 \\
(-0.91)\end{array}$ \\
\hline $\begin{array}{l}\text { establishment size } \\
\text { (number of employees) }\end{array}$ & $\begin{array}{l}0.0007 \\
(1.11)\end{array}$ & $\begin{array}{l}0.0007 \\
(1.15)\end{array}$ & $\begin{array}{l}0.0011 \\
(0.35)\end{array}$ & $\begin{array}{c}0.0009 \\
(0.28)\end{array}$ \\
\hline establishment size squared & $\begin{array}{l}-8.96 \text { e }-9 \\
(-1.02)\end{array}$ & $\begin{array}{l}-9.57 \text { e-9 } \\
(-1.27)\end{array}$ & $\begin{array}{c}-2.54 \text { e-7 } \\
(-0.40)\end{array}$ & $\begin{array}{c}-2.69 \text { e-7 } \\
(-0.43)\end{array}$ \\
\hline $\begin{array}{l}\text { branch plant/subsidiary } \\
\text { (Dummy: } 1=y e s)\end{array}$ & $\begin{array}{l}-0.0607 \\
(-0.35)\end{array}$ & $\begin{array}{c}-0.0698 \\
(-0.40)\end{array}$ & $\begin{array}{c}0.2402 \\
(0.95)\end{array}$ & $\begin{array}{l}0.2031 \\
(0.76)\end{array}$ \\
\hline year dummies & --- & yes $^{* * *}$ & --- & yes $^{\star \star \star}$ \\
\hline $\begin{array}{l}\text { number of observations } \mathrm{N} \\
\text { number of plants } \mathrm{n} \\
\mathrm{X}^{2}(13 \text { resp. } 18) \\
\text { pseudo } \mathrm{R}^{2}\end{array}$ & $\begin{array}{c}5,533 \\
1,411 \\
76.66^{* * *} \\
0.0279\end{array}$ & $\begin{array}{c}5,533 \\
1,411 \\
159.85^{\star * *} \\
0.0489\end{array}$ & $\begin{array}{c}2,010 \\
486 \\
24.32^{\star *} \\
0.0126\end{array}$ & $\begin{array}{c}2,010 \\
486 \\
58.43^{* * *} \\
0.0240\end{array}$ \\
\hline
\end{tabular}

Notes: Robust z-values (based on standard errors adjusted for clustering at the district level) in brackets. ${ }^{* / * * / * * *}$ denote statistical significance at the $10 / 5 / 1$ percent level. $\ddagger$ indicates that the information refers to the previous year.

Source: IAB Establishment Panel, waves 2000-2006; own estimations. 
A striking result of these fixed effects estimations is that only few explanatory variables retain their statistical significance (which may be due to the fact that some variables do not vary much over time). In western Germany, a wage cushion is more likely to exist if the profit situation of the plant is very good or good, and it is less likely if the plant is covered by a firm-level agreement. While the former result is consistent with bargaining or efficiency wage explanations, the latter confirms the relevance of the institutional approach. The regional unemployment rate also proves to be significant in the specification without year dummies but becomes insignificant when (highly significant) year dummies are added (see the second and third column of Table 6, respectively). This implies that it is the cyclical rather than the regional component of the unemployment rate that plays a role - the wage cushion seems to vary more with the business cycle than with regional labour market conditions. In eastern Germany, almost all covariates are insignificant individually, whereas the model as a whole is significant. Notable exceptions are the profit situation of a plant and the year dummies, which again underscores the relevance of the wage cushion in adjusting wages to changing economic conditions.

\section{CONCLUSIONS}

Using a large and representative establishment data set, this paper has shown that in 2006 among plants covered by collective agreements about 46 (20) percent of plants in western (eastern) Germany paid wages above the level stipulated in the relevant collective agreement, giving rise to a wage cushion between the levels of actual and contractual wages. Cross-sectional estimations and fixed-effects estimations for the period 2000-2006 indicate that the (presence of a) wage cushion mainly varies with the profit situation of the plant and with indicators of labour shortage and the business cycle. Moreover, plants which make use of firm-level rather than sectoral-level collective agreements that enable them to take firmspecific conditions explicitly into consideration are significantly less likely to have wage cushions. While our results are (at least partially) consistent with various theoretical explanations, it is interesting to see that outside factors (such as the regional unemployment rate and the business cycle) as well as inside factors (such as establishment profitability) play a role in setting actual wages at the plant level (conditional on given contractual wages).

Coming back to the question in the title of our paper, our empirical analyses indicate that plants with a wage cushion do not pay more than necessary. Quite in contrast, for plants bound by multi-employer agreements it seems necessary to pay wage premiums in order to overcome the restrictions imposed by the rather 
centralized system of collective bargaining in Germany. ${ }^{11}$ This result is consistent with findings for Portugal by Cardoso and Portugal (2005). The responsiveness of the wage cushion to the business cycle also suggests that it gives plants some room for manoeuvre in adjusting actual wages more quickly to changing economic conditions than is possible in the (annual) bargaining rounds which determine contractual wages. Furthermore, the finding that plants with a good profit situation are more likely to pay wages above the contractual minimum might be interpreted as an indication that fairness considerations make it necessary to pay such efficiency wages in order to sustain employee motivation and effort (although it is also consistent with a rent-sharing and thus bargaining explanation).

Against this background it is interesting to see that both bargaining coverage and the incidence of the wage cushion in Germany have declined in recent years. While in 2000 about 42 percent of private sector establishments were bound by a collective agreement, 48 percent of which paid higher actual than contractual wages, in 2006 this was only the case for 33 and 43 percent of establishments, respectively. This has at least two implications: On the one hand, since fewer firms make use of it, collective bargaining seems to have become less dominant in the private sector. On the other hand, for the firms which still adhere to collective bargaining, centralized wage setting seems to have become even more dominant since fewer of these firms deviate from the contractual wages negotiated there by paying higher actual wages. Whether the flexibility of the entire system of wage setting is enhanced by these developments is an open question beyond the scope of this paper. The severe economic crisis of 2008/09 and the reactions of firms in terms of wage setting may provide an answer.

11 Of course it may be asked why firms make use of multi-employer bargaining at all if it poses some constraints on them. Potential answers include saving on transaction cost, profiting from wage moderation in centralized bargaining, avoiding industrial conflicts at plant level, and the cumbersome procedure of abandoning collective bargaining. For an empirical investigation of firms' choice of multi-employer, single-employer or no collective bargaining in Germany, see Schnabel, Zagelmeyer and Kohaut (2006). 


\section{REFERENCES}

Addison, J. T., C. Schnabel and J. Wagner (2001), 'Works councils in Germany: their effects on establishment performance', Oxford Economic Papers 53, 659-694.

Bastos, P., N. P. Monteiro and O. R. Straume (2009), 'Firm heterogeneity and wages in unionised labour markets: Theory and evidence', Labour Economics 16, 440-450.

Bellmann, L. and S. Kohaut (1995), 'Effektiv- und Tarifverdienste in der Bundesrepublik Deutschland: Eine empirische Analyse auf der Basis des IABBetriebspanels', in: K. Gerlach and R. Schettkat (eds.): Determinanten der Lohnbildung, edition sigma, Berlin, 72-93.

Cardoso, A. R. and P. Portugal (2005), 'Contractual Wages and the Wage Cushion under Different Bargaining Settings', Journal of Labor Economics 23, 875-902.

Decken, W. v.d. (1964), 'Die übertarifliche Bezahlung der Arbeiter in der gewerblichen Wirtschaft und im Dienstleistungsbereich im Oktober 1962', Wirtschaft und Statistik 16, 707-712.

Ellguth, P. and S. Kohaut (2007), 'Tarifbindung und betriebliche Interessenvertretung - Aktuelle Ergebnisse aus dem IAB-Betriebspanel 2006', WSI Mitteilungen 61, 511-514.

Fischer, G., F. Janik, D. Müller and A. Schmucker (2009), 'The IAB Establishment Panel - Things Users Should Know', Schmollers Jahrbuch (Journal of Applied Social Science Studies) 129, 133-148.

Gahlen, B. and H. J. Ramser (1987), 'Effizienzlohn, Lohndrift und Beschäftigung', in: G. Bombach, B. Gahlen and A .E. Ott, (eds.): Arbeitsmärkte und Beschäftigung, Mohr, Tübingen, 129-160.

Gerfin, H. (1969), 'Ausmaß und Wirkung der Lohndrift', in: H. Arndt (ed.), Lohnpolitik und Einkommensverteilung, Duncker \& Humblot, Berlin, 472-522.

Gould, F. W. (1967), 'The Dynamcis of Wage-Drift', Economic Record 43, 371-394.

Greene, W. H. (2000), Econometric Analysis, 4th ed., Prentice-Hall, Upper Saddle River.

Gürtzgen, N. (2006), The Effect of Firm- and Industry-Level Contracts on Wages Evidence from Longitudinal Linked Employer-Employee Data, ZEW Discussion Paper No. 06-082, Mannheim. 
Hansen, B. and G. Rehn (1956), 'On wage-drift - a problem of money-wage dynamics', in: 25 Essays in Honour of Erik Lindahl, Ekonomisk Tidskrift, Stockholm, 87-138.

Heilemann, U. and J. Ulrich (2007), 'Good bye, Professor Phillips? Zum Wandel der Tariflohndeterminanten in der Bundesrepublik 1952-2004', in: R. Ohr (ed.): Arbeitsmarkt und Beschäftigung, Duncker \& Humblot, Berlin, 145-180.

Hibbs, D. A. and H. Locking (1996), 'Wage compression, wage drift and wage inflation in Sweden', Labour Economics 3, 109-141.

Holden, S. (1990), 'Wage Drift in Norway: A Bargaining Approach', in L. Calmfors (ed.), Wage Formation and Macroeconomic Policy in the Nordic Countries, SNS, Stockholm and Oxford, 333-358.

Hübler, O. and U. Jirjahn (2003), 'Works Councils and Collective Bargaining in Germany: The Impact on Productivity and Wages', Scottish Journal of Political Economy 50, 471-491.

Kohaut, S. and C. Schnabel (2003), 'Verbreitung, Ausmaß und Determinanten der übertariflichen Entlohnung', Mitteilungen aus der Arbeitsmarkt- und Berufsforschung 36, 661-671.

Külp, B. (1965), Lohnbildung im Wechselspiel zwischen politischen und wirtschaftlichen Kräften, Ducker \& Humblot, Berlin.

Lupi, C. and P. Ordine (1993), 'Testing for independence of wage drift and minimum contractual wage: An empirical investigation using Italian aggregate time series', Labour 7, 161-173.

Meyer, W. (1994), 'Übertarifliche Bezahlung als Anreizinstrument', in U. Hochmuth and J. Wagner (eds.), Firmenpanelstudien in Deutschland, Francke, Tübingen, 219235.

Muysken, J. and T. van Veen (1996), 'Efficiency Wages and Local Wage Bargaining', Scandinavian Journal of Economics 98, 119-127.

Ordine, P. (1996), 'Wage drift and minimum contractual wage: Theoretical interrelationship and empirical evidence for Italy', Labour Economics 2, 335-357.

Pehkonen, J. and J. Viskari (1994), 'Wage drift: Phillips curve vs. bargaining models', Labour 8, 395-421.

Pull, K. (1996), Übertarifliche Entlohnung und freiwillige betriebliche Leistungen, Rainer Hampp, München and Mering. 
Schnabel, C. (1997), Tariflohnpolitik und Effektivlohnfindung, Peter Lang, Frankfurt am Main.

Schnabel, C., S. Zagelmeyer and S. Kohaut (2006), 'Collective Bargaining Structure and its Determinants: An Empirical Analysis with British and German Establishment Data', European Journal of Industrial Relations 12, 165-188.

Stephan, G. and K. Gerlach (2005), 'Wage settlements and wage setting: results from a multi-level model', Applied Economics 37, 2297-2306.

Weiss, A. (1991), Efficiency Wages: Models of Unemployment, Layoffs, and Wage Dispersion, Princeton University Press, Princeton. 


\section{APPENDIX}

Appendix Table: Summary statistics of the sample used in Tables 4 and 5 (2006)

\begin{tabular}{|c|c|c|c|c|}
\hline \multirow{2}{*}{ variables } & \multicolumn{2}{|c|}{ western Germany } & \multicolumn{2}{|c|}{ eastern Germany } \\
\hline & mean & std. dev. & mean & std. dev. \\
\hline $\begin{array}{l}\text { presence of a wage cushion } \\
\text { (dummy: actual wages above } \\
\text { contractual wages }=1 \text { ) }\end{array}$ & 0.5358 & 0.4988 & 0.2485 & 0.4323 \\
\hline $\begin{array}{l}\text { size of the wage cushion } \\
\text { (in percent) }\end{array}$ & 5.5052 & 7.8332 & 2.6593 & 6.4147 \\
\hline $\begin{array}{l}\text { regional unemployment rate } \\
\text { (at district level, in percent) }\end{array}$ & 11.0058 & 3.9852 & 18.7935 & 2.9573 \\
\hline $\begin{array}{l}\text { vacancy rate } \\
\text { (in percent of employment) }\end{array}$ & 1.9005 & 46.1040 & 1.3060 & 7.3067 \\
\hline $\begin{array}{l}\text { vacancies for qualified jobs } \\
\text { (share of all vacancies, in percent) }\end{array}$ & 15.7524 & 36.0988 & 11.5045 & 31.5766 \\
\hline $\begin{array}{l}\text { share of qualified employees } \\
\text { (in percent) }\end{array}$ & 73.2238 & 24.9738 & 85.3039 & 20.6520 \\
\hline $\begin{array}{l}\text { share of part-time employees } \\
\text { (in percent) }\end{array}$ & 19.1555 & 23.0400 & 14.9522 & 23.3076 \\
\hline $\begin{array}{l}\text { share of female employees } \\
\text { (in percent) }\end{array}$ & 35.0147 & 29.0970 & 34.3534 & 29.6620 \\
\hline $\begin{array}{l}\text { profit situation } \\
\text { (dummy: very good/good=1) }\end{array}$ & 0.3297 & 0.4702 & 0.3817 & 0.4860 \\
\hline $\begin{array}{l}\text { modern production technology } \\
\text { (dummy: } 1 \text { or } 2 \text { on } 5 \text {-point scale=1) }\end{array}$ & 0.6575 & 0.4746 & 0.7071 & 0.4553 \\
\hline $\begin{array}{l}\text { works council } \\
\text { (dummy: 1=yes) }\end{array}$ & 0.4602 & 0.4985 & 0.4039 & 0.4909 \\
\hline $\begin{array}{l}\text { covered by firm-level agreement } \\
\text { (dummy: 1=yes) }\end{array}$ & 0.1213 & 0.3266 & 0.2417 & 0.4283 \\
\hline $\begin{array}{l}\text { establishment size } \\
\text { (number of employees) }\end{array}$ & 306.6333 & 1451.196 & 122.1366 & 332.8158 \\
\hline $\begin{array}{l}\text { branch plant/subsidiary } \\
\text { (dummy: 1=yes) }\end{array}$ & 0.2259 & 0.4182 & 0.2562 & 0.4367 \\
\hline $\begin{array}{l}\text { difficulties in hiring skilled workers } \\
\text { expected (dummy: 1=yes) }\end{array}$ & 0.2945 & 0.4559 & 0.2297 & 0.4208 \\
\hline $\begin{array}{l}\text { insufficient employee motivation } \\
\text { expected (dummy: } 1=y e s \text { ) }\end{array}$ & 0.0971 & 0.2962 & 0.0529 & 0.2240 \\
\hline
\end{tabular}

Notes: Unweighted data, only plants in the private sector covered by a collective agreement Source: IAB Establishment Panel, wave 2006 